\title{
Bringing Life to EFL Classes by Creative Drama
}

\author{
Filiz RIZAOĞLU* \\ Dokuz Eylül University
}

\begin{abstract}
Creative Drama is an informal and improvisational form of drama, created by the participants. As a teaching tool it blents -rrett nithithe teaching of English as a foreign language. Taking into consideration the monotony and artificiality in the traditional learning settings, the strong link of creative drama with the real world and daily life makes it one of the most effective and communicative methods of language teaching and learning. This paper presents creative drama as a studentcentered and real-to-life way of teaching English. It also introduces the phases of the process and states the rationale for using it in the classroom as well as the benefits offered to the students. Finally ways of incorporating creative drama in the EFL syllabus are suggested.
\end{abstract}

Keywords: Drama- in-education, creative drama, phases of creative drama, EFL

\section{Özet}

Yaratıcı drama katılmalar tarafindan oluşturulan biçimsel olmayan ve doğaçlama bir drama çeşididir: Bir öğretim aract olarak yaratıcı drama kullanımı yabanct dil olarak Ingilizce ögrretimine uygundur: Geleneksel öğrenme ortamlarıntn gerçek yaşamdan kopukhığı ve sıktctllğı göz önüne alındığında, yaratıcı drama, iletişime verdiği önem ve yaşamla olan sikı bağlartyla en gïncel öğretim yöntemlerinden biri olarak karşımıza çımaktadı: Bu çalışma öğrenci merkezli ve gerçek yaşama yakın bir Ingilizce öğretme yöntemi olan yaratıcı dramayı tanttmayt amaçlamaktadn: Ayrtca yaratıcı drama sürecinin așamalart tanttlmakta, yöntemin sminfortamında kullanilmasımm gerekçesi verilmekte ve öğrencilere sunduğu yararlar ïzerinde durulmaktadır. Son olarak yaratıcı dramay Ingilizce ders programlarma dahil etmek için birtakım önerilerde bulunulmuştur:

Anahtar sözcükler: Eğitimde drama, yaratıc drama, yaratıcı dramanın aşamalart, yabancı dil olarak ingilizce eğitimi 


\section{Introduction}

One of the earliest forms of the arts, drama has always been a part of human history. As Shakespeare stated long ago "The world is a stage, and all the men and women merely players". [1] People, as the participants of the play called "Life" also encounter drama in the theater, on TV, on radio and even on the street. Another place that people have the opportunity to meet drama, perhaps for the first time in their lives is the school, which is of concern in this paper.

By "drama in school", the use of drama as a tool for teaching is referred to, rather than drama education. The first educational practices of drama can be traced to ancient Greece. In the medieval ages drama became a tool for teaching religion. McCaslin (1999, p.255) reports that although the history of drama as a teaching instrument dates back to ancient times, the styles and techniques of using drama in education have changed extensively in our age. In the 1950s and 60 s Slade and Way were the important figures, who focussed on the developmental aspect of drama as a device for increasing self-expression and creativity of children (Dougill, 1987, p. 3). Heathcote followed them in the 1970s with her emphasis on self-expressive power and individual freedom encouraged by creative drama. In the same period Bolton (1986) acknowledged the role of drama in language development. In Turkey, dramatization as a teaching technique was incorporated in the primary school curriculum in 1926 (Üstündağ, 1999). In the 1980s creative drama gained ground with some theoratical and practical studies conducted by San, Levent and further on Adigüzel and others. It has also become a compulsory course for kindergarten and primary school teacher trainees in 1998 (Tuluk, 2004).

Today, ways of incorporating drama in every aspect of the curriculum are being sought. A large portion of these efforts attempt to increase the role of drama in English teaching. The use of "Creative Drama" in foreign language teaching has emerged as an outcome of this trend. This highly improvisational and informal kind of drama, which guides the learners to explore themselves by creating dramatic situations of their own is gaining in popularity among the English teachers all over the world.This paper aims to introduce the use of creative drama in English language teaching as a highly valuable aid and a real-to-life tool. It also discusses the numerous benefits offered to the learners of English as a foreign language and suggests some ways to incorporate creative drama in the EFL classrooms.

\section{Creative Drama As a Learning Proces}

\section{A. Basic Features}

Drama in the classroom is referred to as Drama-In-Education in Britain and Creative Drama in the USA, to distinguish it from theater arts. Creative drama is a broader term covering the terms creative dramatics, role playing, improvisational drama and educational drama. The official definition of the field is:

"Creative drama" is an improvisational, nonexhibitional, process-centered form of drama in which participants are guided by a leader to imagine, enact; and reflect upon human experiences. Although creative drama traditionally has been thought of in relation to the children and young people, the process is appropriate to all ages. [2]

Creative drama is an active process, in which an idea, concept, story, poem or a situation is enacted by the learners without any preparation, as it happens to themselves during the enactment. In this sense, creative drama allows the learners to reflect on their English learning by using it as a medium of expression. Prompting the process by means of a communicative function of language or a situation considered to be tempting for the students makes a link between the learning process and the real life. It is this connection with real life that leads the language learner to discover ways of expression.

Using literary products of the language, such as a story or a poem to create drama greatly enhances language learning. In addition to having links with real life, it provides the learners with 
perfect examples of the target language through the literary works. At this point, it should be emphasized that creative drama is not the literary interpretation of plays or written work, which is the concern of theater. As it is not learning about drama, but learning through drama, creative drama aims to develop the learners, not the art of theater,which requires acting skills and special training. Buchanan (1998) summarises the difference by representing drama as 'a thing done'and theatre as 'a thing to gaze'. This is quite reasonable since the root of drama- dran means "to do" in Greek (Tuluk, 2004). In the illustration below, further differences between theater and creative drama are listed as an attempt to show the distinction of creative drama as a learning process.

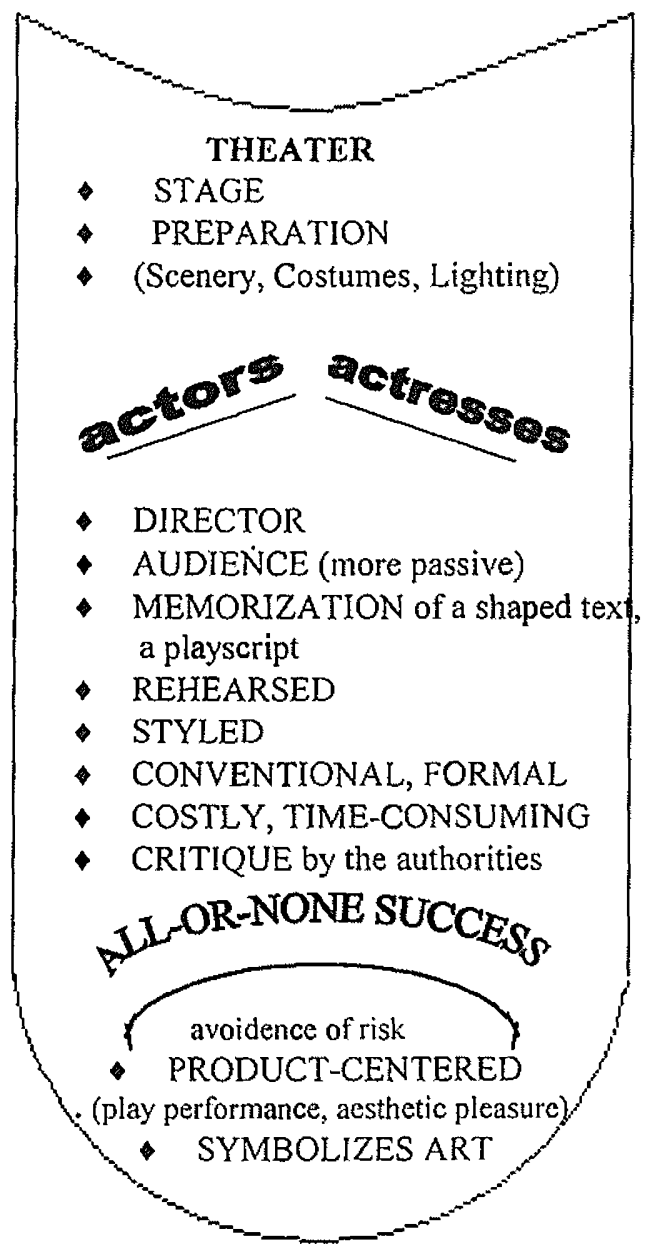

\section{B. Phases of Creative Drama}

An English teacher, intending to teach English through creative drama cannot simply enter the classroom and say, "Today, we will try performing creative drama. Now, form a group". Students, who have never experienced creative drama cannot be expected to perform it immediately. Considering that even native speakers need certain amount of exposure to drama before taking part in it, it is natural that foreign language learners will have some difficulties at first. In order to minimize these effects, first the students should be motivated by activating their drama skills. This can be achived by following the steps of using creative drama in English classes as sug-

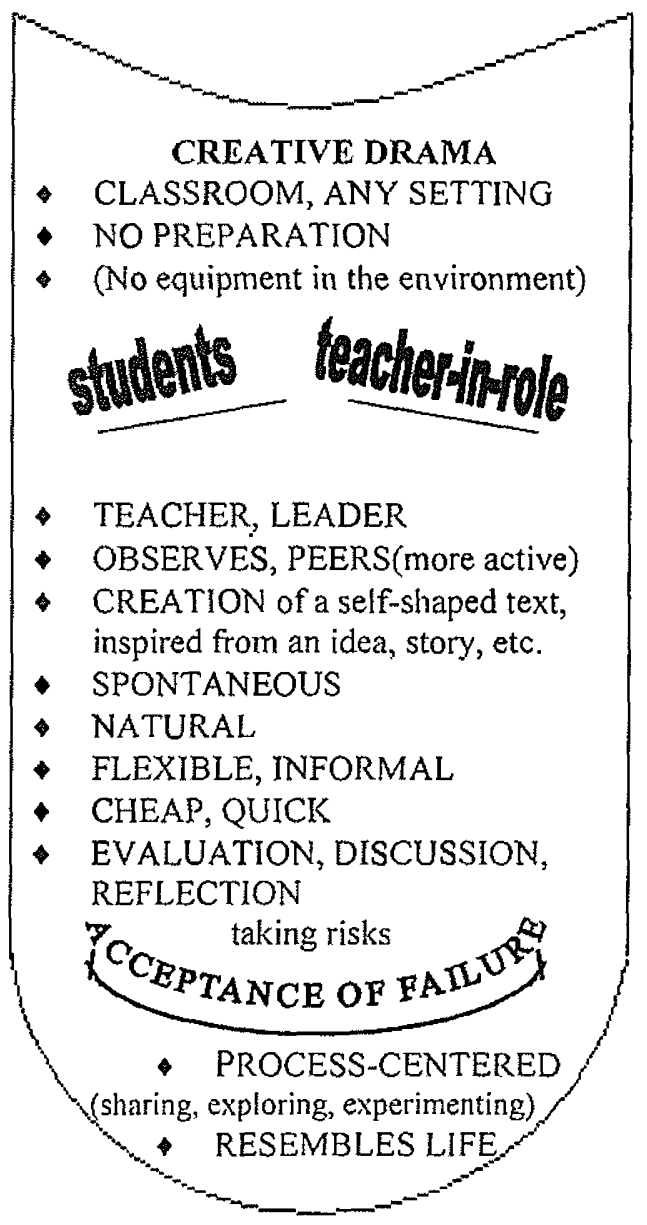

Figure 1

The Difference Between Theater And Creative Drama [3] 
gested by Bushman (2001, pp. 52-61). Through warm-ups, pantomime and role-playing students should be familiarized with the dramatic process. Thus, in the proceeding stages they can be encouraged to create improvisation, which is the essence of creative drama. Finally, the evaluation part must proceed to give feedback on the whole process. It is essential to analyze each phase of creative drama in detail since it is basically a progressive process.

\section{Warm-ups}

The main function of warm-ups is to establish a comfortable atmosphere for the learners to create drama cooperatively. It involves trustwork and physical activities. Warm-ups can be studied under two headings: non-verbal and verbal.

\section{i ) Non-Verbal Warm-ups}

Before starting the non-verbal warm-ups, the physical setting, the classroom should be convenient for the students to move along freely. Arranging the desks in $u$-shape may help to create enough space to carry out the activities. Simple non-verbal warm-ups include mirrors, tug-of-war, Simon Says, etc. In the mirroring activities, for example, one student acts as a mirror of another one imitating whatever he/she does.

\section{ii) Verbal Warm-ups}

Verbal warm-ups may precede or follow pantomime, word games, tongue-twisters, riddles, ball games lend themselves to verbal warm-ups well. Ball games can be considered as a transition from non-verbal to verbal warm-ups. A student may throw the ball to one of his/her classmates and ask him/her a personal question about his/her hobbies, interests, etc. Thus, interaction can be maintained throughout the class. A word game, which requires the students to say a word beginning with the last word uttered by another student, can be fun and motivating.

Through warm-ups students' attention can be channeled into one activity and they can feel more confident to carry out pantomime and improvisation activities.

\section{Pantomime}

In order to acquaint students with pantomime, they can be asked to express an emotion such as "excitement, surprise, fear, etc." by the help of their mimics and gestures. In vocabulary teaching the meaning of a new word can be introduced by pantomime or as a follow-up activity the students can pantomime the word. Bushman (2001, p.55) states that "Classroom research tends to support the notion that using pantomime as well as improvisation and role-playing increases student retention of vocabulary meanings.". Another suggested language activity with pantomime is a guessing game, which is very popular in every walk of life. In this popular game named charades, a student comes into the front of the classroom and pantomimes the name of a movie, book, etc. or a sentence such as "May I open the window?" Thus, even a learner who is hesitant to speak in the classroom has a chance to take part in the activity by just miming. The rest of the class tries to guess what he/she is trying to tell. These games can create a competitive atmosphere in the classroom, which provides a more dynamic learning.

\section{Role-playing}

In role playing students are asked to "identify with fictitious characters and to speak and behave in the some way as they think these people would." (Jones, 1978, p.10). Using masks or puppets in role playing may help the student in identifying with the character. Role-plays are widely used in English language teaching and their value in promoting oral perfromance and linguistic awareness is acknowledged by researchers (Brice, 1993; Horwitz, 1985). DiNapoli (2003) points out that the benefits of role-playing to language learning are manifold:

The character research preparation will affect the overall language used and the functional strategies employed during the peformance of the role-play. This in turn will make the activity more consistent with the other objective of the role play activity, which is to get students to communicate on a broad range of topics in a way which is as 
near as possible to authenticity in the classroom context. (p. 34)

Some situations that can be used in role playing are suggested below:

- To make students aware of the role of the participants, register and style in a conversation, some students may be asked to role play different situations. In the first conversation a group of youngsters talk about the pop groups. In the second conversation some elderly ladies talk about the past days. In the third conversation a talk takes place between the boss and his employees. After role playing the students discuss the differences of vocabulary, structure and the content of the three conversations.

Students role play a part of a story, novel, play or a poem they have studied in the classroom.

- In order to practise intonation and stress, some dialogs can be written by the students. The dialog should include elements of surprise, exclamation, doubt, questioning so that intonation of the sentences can be exercised. Imaginary occasions involving famous people can be interesting if handled in an amusing way.

\section{Improvisation}

McCaslin (1998) explains improvisation as "the creation of a situation in which characters speak spontaneously" (p.106). Although students may become accustomed to drama through pantomime and role playing, it may still be difficult for them to improvise.Beginning improvisations with simple, familiar situations and expanding the activity subsequently is recommended. To exemplify, the students may be asked to make an improvisation about a quarrel between a mother and son.

Memorization of dialogs may be useful in a class which is not accustomed to improvisation. It also has a great impact on the later recall of words. In a study conducted by Shacker, Juliebo and Parker in 1993 (cited in Saldana, 1995) it was found out that the use of memorized playscripts assisted with the retention of the foreign language months later.

Other improvisation activities include:

Foreign film [4]: 2-4 actors do the acting and 2-4 other actors do the voices. The audience gives the actors a scene-the actors act it out and the others dub their voices.

- Family reunion [4]: It is summertime and the members of a large family is coming together in one of the members' house. The members of the family are interesting people with different backgrounds-a pop singer, a politician, a farmer, a teacher, an actor, etc. They meet at dinner table and start a conversation.

- Popular TV programs such as talk-shows and reality programs can be acted out. The performances may be recorded in video cassettes and as a follow-up activity, the program texts can be written by the students.

- Vocabulary work: The students are given the dictionary meaning of a word, phrase or idiom. They are asked to explain the meaning by improvisation.

e.g. "all thumbs" (clumsy). A student goes to an imaginary supermarket. $\mathrm{He} /$ she first slips on the floor, then trying to look at the glass objects on a shelf, he/she breaks a vase, etc.

Students may also be given a list of words and phrases and asked to use them in their improvisations. In this way these words become part of the students' active vocabulary. An investigation carried out by Wright (1996) indicated a significant growth in students' vocabulary as well as roletaking ability and development of self-concept after taking part in a 10 week creative drama program based on improvisation. Alber and Foil (2003) have also tried to demonstrate introducing new vocabulary items through creating memorable events such as the ones above in order to maintain retention. 


\section{Evaluation}

Evaluation can be done prior to the performance, during or after the performance. In this phase, discussions, criticisms, self-evaluation and reflections have an important place. The criticisms are addressed to the roles and characters, not to the participants. When the experiences are shared and talked over, they become more meaningful and so they can easily be remembered later on (Koç \& Dikici, 2003). The group leader, usually the teacher guides the students to express what they have felt. The class may evaluate their fluency and accuracy in speaking English spontaneously. The most common pronunciation mistakes can be discussed. In the discussions, students are encouraged to speak in English, as they are expected to do in the previous phases. In this way students speak English more frequently and their oral production skills improve.

\section{What does creative drama offer?}

The things creative drama offers are numerous as the process itself is of a diverse nature combining various activities, skills, senses, and emotions. It can be compared to a melting pot in which different flavors of life are mixed together to create a unique performance. In this sense it is hard to classify the benefits offered to practitioners. Like a chain-effect system it first boosts the learner's confidence and ease in the learning environment and proceeds to improve the learner's oral, social and academic performance. Thus a learner of English may receive not only linguistic but also psychological and cognitive benefits from the practice. Waldschmidt (1996) makes a list of these as "Creative drama comprises the use of imagination-improvisation to develop communication skills, creativity, social awareness, clarification of values/attitudes, empathy, positive self-development". The following classification may serve to illustrate the possible gains that can be obtained by EFL learners through the multidimensional universe of creative drama.

\section{A. Benefits to the Learner as an Individual}

\section{Positive Self-Concept}

Creative drama makes students aware of their identities by directing them to find their strong and weak points, likes and dislikes; it allows for self-control and regulation (De La Cruz, 1995). It provides them with the opportunity to experience new things and to take risks. By the help of a hypothetical situation, students apply their world knowledge to cope with the possible problems. Using the dramatic situation as a testbed, students gain confidence and as a result have a positive self-concept. Creative drama's influence on the self-concept has been confirmed by several studies, such as Wright's (1996), which was mentioned earlier. Another study conducted by Gourgey, Bosseau and Delgado in 1985 (cited in Saldana, 1995) proved that after a 6 month improvisational drama project, gains were observed in attitude areas including trust, selfacceptance, acceptance of others and empowerment. Furthermore, it is usually observed that shy students break the ice in the new atmosphere of drama by hiding behind their masks or roles. As drama provides an opportunity for a healthy release of emotion, it is beneficial for both introvert and extrovert students.

\section{Problem Solving Skills}

Creative drama is a representation of life, with one big difference: it has no boundaries. You can be whoever you are, you can do whatever you wish, as far as your imagination allows. By solving the dramatic tension, students develop problem solving strategies, which will be of great use in real life. Goalen and Hendy (1993) support this view with their observation of an increase in thinking skills of the students exposed to drama in social studies. Heinig and Stillwell (1974) confirm this effect by emphasizing that creative dramatics aids in "developing language arts skills; improving socialization skills; stimulating creative imagination; developing an understanding of human behaviors; and participating in group work and group problem solving". Annarella (1992) elaborates as "It is an internal form that can be used in an operational mode when divergent skills are needed in problem solving". 


\section{Creativity}

As its name suggests creative drama fosters especially the child's imagination (McCaslin, 1998; Waldschmidt, 1996) and leads him/her to find new ways of tackling a problem (Dougill, 1987). It stresses that there is more than one option in the world. Furthermore, creative drama saves students from the limitations of the test-oriented education.

\section{Appreciation of the Theater Arts}

Although creative drama has many different features from that of theater, the two have the same driving force behind themselves: life. A student, who is familiar with creative drama, will naturally be more interested in theater than a student who is not familiar with it (Walschmidt, 1996). He/she will view the theater from a different perspective. Further encounters with theater may help the student to choose acting as a profession.

\section{B. Benefits to the Learner as a Social Being}

\section{Social Awareness}

Creative drama builds an understanding among the students (Bolton, 1986; Lunz, 1974). As they put themselves in the others' shoes they begin to develop empathy (Stern, 1980, p. 81). In this sense they can better understand why people feel the way they do or why they do a particular thing. Courtesy to others and social compliance are the areas that De La Cruz (1995) found to hold a positive effect of creative drama on the participants. Stern (1980) points out that development of empathy is possible through involvement in creative drama.

\section{Cooperation}

Creative drama involves groupwork. Since the group works as a whole to create a shared experience the level of peer interaction increases (Schaffner, Little \& Felton, 1984). Everyone has his/her role in this experience, so everyone is important for the group. The differences between the students pose no problem, as variety is the spice of drama. The harmony arising from the union of different characters is an essential feature of creative drama.

As it views the participants central to the process, creative drama adopts a highly humanistic approach to learning. The primary aim of creative drama is the personal growth of the people from all aspects-emotional and intellectual, affective and cognitive. Seen in this light, a learner who has a positive self-concept and social awareness may be a better language learner, as he/she will have removed the psychological or social barries in front of him/her.

\section{Benefits to the Language Learner}

As Brand (1979) explains "Drama in language learning is not a new idea". Dramatic techniques such as role-plays, simulations are widely used in EFL classes. Books advocating the use of drama in language learning/teaching are plenty in number (Butterfield, 1989; Dougill, 1987; Holden, 1981; Maley\&Duff, 1982). However, there has been a new interest in the cooperation between creative drama and language teaching. The two fields; creative drama and language education have much in common. Both are ways of expressing people's ideas and emotions. Creative drama uses language to achieve this aim, so why not use creative drama to teach languages?

\section{Creative Drama as a Learner-Centered} Language Learning Method

Anneralla (1992) asserts that "used as a classroom methodology creative drama can provide a student-focused for learning" (p.2). Creative drama offers a rich learning environment taking into account both the similarities and differences between learners. Ginnis (2002, p.17) lists four similarities between learners. Creative drama meets each of the requirements to its full potential:

\section{i) Everyone needs to work things out for themselves.}

In creative drama each learner is responsible for his/her own performance or study. Having a different background, each student interprets 
his/her role in a different way. All the students actively take part in an activity by resorting to their previous experiences. Therefore, creating characters and situations is a subjective process, which brings together past and present learning experiences. In this way, the new learning situations created by means of drama are better personalized or internalized, allowing for a longer period of retention. The adage "Tell me and I forget, teach me and I remember, involve me and I learn" summarizes this item.

ii) Experiences that are multisensory, dramatic, unusual or emotionally strong are remembered for longer and in more detail than ordinary, routine experiences.

This item seems to involve the gist of using creative drama in the EFL classroom. To begin with, creative drama offers new stimuli to the learners. In other words, it provides the learners with novel situations to prompt learning. Secondly, when more than one sensory route is used in the learning process, there is a better chance of retention, which is of great importance in foreign language teaching, especially in vocabulary teaching.

A study conducted by Ekwall and Shanker (1998) provides further evidence, the results reveal that people generally recall about:

$-10 \%$ of what they read

$-20 \%$ of what they hear

- $30 \%$ of what they see

- $50 \%$ of what they both see and hear

$-70 \%$ of what they say

$-90 \%$ of what they simultaneously say and do.

As creative drama involves all the senses, it can be claimed that the language items learned or used through drama will have a better chance of retention.

iii) Everyone needs to feel emotionally secure and pscyhologically safe.

The warm-ups preceding the actual creative performance, as well as the creative process itself aims to achieve this goal. In order for learning to take place, students should direct their attention to the learning situation. Batista (2005) notes that "Creative dramatics in the ESL classroom involves techniques that will contribute to lowering [language anxiety]. The numerous activities presented allows for students to learn in a nonthreatening environment and where they are the initiators of communication" (p.53). As can be seen creative drama removes the affective barries in front of learning by its experimental and flexible nature. There are no "rights" or "wrongs", consequently no fear of making mistakes. Even if students make mistakes it will not be seen as a matter of life and death. The laughter will enhance the informal atmosphere of the classroom.

iv) Learners are more motivated, engaged and open when they have some control over their learning.

Creative drama provides the learners with a freer learning environment in which they are not surrounded by strict rules and principles. If the learners are asked to choose the activities or topics to be used in creative drama, their initiative power will improve. As a consequence they will be aware of which language items are more necessary to learn, considering their needs.

With regard to learner differences creative drama is an effective teaching tool, too. It values learner differences and brings together learners of varying interests to create a performance of harmony. As commonly recognized today Gardner (1993) has listed seven types of intelligences: Linguistic/Verbal, Logical/ Mathematical, Spatial/Visual, Bodily/Kinesthetic, Musical/Rythymic, Interpersonal, Intrapersonal, Naturalist/Existential. In view of the MI theory creative drama is ideal for students with various dominant intelligences. Gardner also acknowledges the power of drama in comprising a multitude of intelligences; "I certainly believe that theater involves a multiplicity of intelligences". [5] The pioneers of an arts-in-education organization explain how this is possible: 
Creative Drama activities and scenework require spoken language, improvisation, visual skills, geometric thinking, memorization, the ability to work with others, a sense of musicality and rhythm, and knowledge of and use of one's body to project thoughts and feelings. [6]

\section{Creative Drama as a Language Centered Process}

As Bolton (cited in Dougill, 1987) simply puts it "Drama is a unique tool, vital for language development". Actually Stewig's survey (1986) reveals that two thirds of the time allotted to drama activities at schools were related to language arts and reading which are components of language development tools. A series of earlier studies by Pellegrini $(1982 ; 1984)$ show that the use of dramatical techniques in education fosters language development in children. These imply that drama can also have positive effects on foreign language development. Schaffner, Little and Felton (1984) seem to have found the reason for this, "Drama provides opportunities for children to use language for a wider variety of purposes than otherwise typically occurs in classrooms". In the same way, creative drama addresses to all four macro skills of language in the following order: Speaking, Listening, Reading and Writing. The priority is given to speech as in real life.

\section{a. Primacy of Speech}

The oral skills, which can be improved greatly by means of creative drama are often neglected by the language teachers. This is often due to the fact that evaluating an oral performance objectively is a difficult matter. Nevertheless in creative drama, evaluation is handled in a completely different way. The result of the evaluation is not a matter of critical importance, like the marks. The evaluation of the oral activity is done by the learners, which prevents the danger of misjudgements.

A research carried out by Lepley (2001) has indicated that using creative dramatics, especially puppetry aides the ESL students in oral language development. The learmers have a chance to put their grammatical, lexical and phonological knowledge into use during the dramatic process. As they practise creative drama, their fluency improves. The use of creative drama not only enhances fluency but also variation of tone, style and expression depending on the different roles the learners assume. The students acquire better habits of speech, subconsciously learning to manage their tempo, volume and intonation. In this way, the learners become more sensitive to the target language.

In addition to giving the learners a chance to speak, creative drama involves a lot of listening. Learners have to listen to their partners carefully in order to respond to them. While trying to make meaning out of the oral input, the learner is actually learning to comprehend language. Oral-aural skills are the main concern of creative drama. Podlozny's study (2000) into strenghtening verbal skills through drama demonstrated positive effects in not only oral language development but also written and oral measures of story recall, reading achievement, reading readiness, oral language development, and writing. The results were found to be "very encouraging for educators who use drama in the classroom in expectations of achieving greater verbal development"(Podlozny, 2000)

\section{b. Reading and Writing}

At first, the correlation between reading and writing and creative drama seems questionable, but there certainly exists a link between the two, though it is an indirect one. Since creative drama improves students' oral language skills, the improvement in that area will affect the overal development of language skills. Heathcote and Wagner agree that "the oral language skills developed through drama have also been found to facilitate students' writing skills" (cited in Tatar, 2002). Drama has also been found by McCaslin (1999) to be helpful for reading skills: McCaslin argues that "most teachers find drama to be a strong motivation for reading and vocabulary building" (cited in Tatar, 2002). Moreover, mak- 
ing use of literary works in creative drama integrated EFL classes will aid reading skills. The other way round, using the process in literatureoriented classes will make the interpretation of the texts easier. A group of learners improvising a situation taken from a story will hold all the students' interest alive. They will be in the shoes of the characters in the story, which will give them the chance to comment on the work more easily. DuPont (1992) found that fifth grade remedial reading students' comprehension skills were improved by a creative drama integrated reading program which centered on children's literature.

In the evaluation phase of creative drama, students reflect on their experiences either orally or by writing them. Apart from this, they can write the texts of what they have improvised by taping the performance on audio or video cassettes. These are meaningful and interesting on the learner's part as the target language is used write about personal experiences. Research findings are also in line with this assumption (Anneralla, 1999; Pellegrini, 1980; Podlozny, 2000).

\section{c. Links With ELT Methodology}

Creative drama by its nature is a highly communicative process. Although there is no specific psychological or linguistic theory behind it, it can be considered within the scope of the communicative approach. Given its close link with real life, its emphasis on learner needs, flexibility, fluency and support for creativity creative drama resembles the communicative approach. In addition to this, the situations which encourage the students to try out the functions of language are part of the functional-notional syllabus. Therefore, teachers adopting the communicative approach to language teaching as well as the others can incorporate creative drama in their syllabi without giving it a second thought. It is of vital importance to note that the adoption of creative drama as an aid to teach foreign languages other than English will also prove to be highly fruitful since language learners learners follow similar paths in their route to proficiency in a foreign language.

\section{Incorporating Creative Drama in the Classroom}

\section{Strategies}

Language teachers can use creative drama for different purposes: to present a new material, to practice a learnt item or simply to liven up the classroom. Before starting the performance, the desks can be arranged in U-shape to allow for enough space or the students can work from their desks (Butterfield,1989). The teacher can use a special prompt the start the process, such as a clap, a bell, etc.

It is recommended for the teacher to start the dramatic process with simple warm-up activities and then to proceed with improvisation. Depending on the concern of the lesson, the teacher is free to choose a dramatic activity that fits the objectives. The decision making process can be handled by the students, too, for they will be responsible for their own learning.

\section{Learner Roles}

The center of creative drama is the learner. It might not be wrong to suggest that the whole process belongs to the learners. The learners' main tasks are improvising through target language and reflecting on the performance. Heathcote (1995) terms the role of the learner as "the mantle of the expert". Adopting this role, students are given roles that give them expertise and responsibility in an imaginary area. In this way they have the authority of making decisions of their own. Stewig notes that "some of the techniques used in creative drama such as mime, movement exercises or invented dialogue give every child an opportunity to be actively engaged in drama without necessarily having to act or speak" (cited in Tatar, 2002).

\section{Teacher's Role}

The teacher's role in creative drama is that of a facilitator or a guide. The teacher's role can be teacher-in-role, too, that is the teacher takes part in the drama. In fact, a teacher resembles an actor in that he/she stands in front of the classroom"the stage" and addresses a crowd of students- 
"the spectators". Therefore, any teacher can join in the drama without having difficulty as he/she is familiar with the task through his/her job. However, as Heathcote (1995) suggests the teacher should not play the authority roles in order maintain a student-centered activity.

According to Gasparro (1994) it is also the responsibility of the teacher to "model oral expression and to establish an acting workshop atmosphere". The teacher may help the students when they cannot find the right word to express themselves. In order to make students aware of their language use, he/she can take notes of the students' errors. In this case, creative drama takes the shape of a diagnostic tool. However, it is not advisable to correct the mistakes immediately, as it will hinder fluency.

\section{Conclusion}

Creative drama, which is basically an improvisational form of drama is an invaluable instrument for teaching English as a foreign language. In an era, in which the major trends in ELT methodology favor student-centered, communicative ways of teaching touching real life, creative drama stands out as a unique method meeting the current demands.

The dramatic process is an incremental one, starting with simple warm-ups and proceeding with creative and autonomous improvisations. In this process students gain various developmental, educational and linguistic benefits, regardless of their ages. Moreover the learning environment is livened up owing to creative drama's power of creating fun and dynamism, which are the elements of real life. Taking everything into account, the implications for the English teachers are clear. Effective use of creative drama in the EFL classroom will result in effective and "real" learning/teaching.

\section{Notes}

[1] William Shakespeare. As You Like It. Act 2 Scene 7 . (From the famous speech of Jacques)

[2] Jed H. Davis and Tom Behm. (1978) Terminology of Drama/Theatre with and for
Children: A Redefinition, Children's Theater Review. Vol. 27. pp. 10-11.

This definition, along with those for Children's theater, were accepted by the Governing Board of the Children's Theater Association of America

[3] Developed by the author based on the list written by Saldana (1995)

[4] Adapted from Workshop Material for Creative Drama (1998) Retrieved October 18, 2004 from http://www.kmrscripts.com/edguide.html.

[5] Cited in the website of Theatre in Motiona participatory, educational theatre company. Retrieved April 23, 2006 from

[6] Why use creative drama in the classroom? Retrieved April 23, 2006 from http://www.youthstages.com/CreativeDrama/WhyCD.asp Youth Stages, LLC, based in Princeton, New Jersey, USA.

\section{References}

Alber, S. R. \& F., C. R. (2003). Drama activities that promote and extend your students' vocabulary proficiency. Intervention in School \& Clinic, 39(1), 22-29.

Annarella, L. A. (1992). Creative drama in the classroom. Washington D.C.: Office of Educational Research an Improvement. (ERIC Document Reproduction Service No. ED 391 206).

Annarella, L. A. (1999). Creative drama in the writing and reading process. Washington D.C.: Office of Educational Research an Improvement. (ERIC Document Reproduction Service No. ED 445 358).

Batista, G. (2005). Teaching wnits to lower anxiety for $8 t h$ and 9th grade ESL students in Puerto Rico. Unpublished masters thesis. Mayaguez.

Brand, M. (1979). The Drama in Language Teaching Workshop. TESOL Newsletter 19,2: 19.

Brice H. S. (1993). Inner city life through drama: Imagining the language classroom. TESOL Quarterly 27,2,177192.

Bolton, G. (1986) Selected writings in drama education. London: Longman Publ.

Buchanan, T. (1998). Definitions and discussion of important terms. Retrieved October 19, 2004 from http://www.chiddrana.com/mainframe.html

Bushman, J. (2001). Teaching English Creatively. Springfield: Charles. 
Butterfield, T. (1989). Drama Through English Through Drama. Banbury: Kemble Press.

De La C., R. E. (1995). The effects of creative drama on the social and oral language skills of children with leaning disabilities. Unpublished EdD Dissertation, USA: Illinois State University

DiNapoli, R. (2003). Towards natural engagement in nonexhibitional dramatic role-plays. Iberica 6,15 38.

Dougill, J. (1987). Drama Activities For Language Learning. London: Macmillan.

DuPont. (1992). The effects of creative drama as an instructional strategy to enhance the reading comprehension skills of fifth-grade remedial readers. Reading Research and Instruction, 31, 3: 41-52.

Gardner, H.. (1993). Frames of Mind. London: Fontana Press.

Gasparro, M.-F. (1994). Creating drama with poetry: Teaching english as a second language through dramatization and improvisation. Retrieved October 27, 2004 from http //www.cal.org/ericcll/digest/gaspar01.html./

Ginnis, P. (2002). The Teacher's Toolkit. Glasgow: Crown House.

Goalen, P., \& H., L. (1993). Developing children's historical thinking through drama. The Curriculum Journal, 4 , 363- 384

Heathcote, D. and B., Gavin. (1995). Drama For Learning. Portsmouth, NH: Heinemann.

Heinig, R. and S., L. (1974). Creative Dramatics For The Classroom Teacher. NJ: Prentice-Hall.

Holden, M. (1981). Drana in Language Teaching. Essex: Longman.

Horwitz, E. K. (1985). Getting them all into the act: Using audience participation to increase the effectiveness of role-play activities. Foreign Language Annals, 18, 3, 205-208.

Jones, P. (1978). Act English. London: Penguin.

Koç, M. \& D., H. (2003). Eğitimde Dramanın Bir Yöntem Olarak Kullanılması. Ilkögretim Online, 1. Retrieved September 23 from http://ilkogretimonline.org.tr/vol2sayl/oul/oul.pdf.

Lepley, A. N. (2001). How puppetry helps the oral language development of language minority kindergartners. Retrieved October 10, 2004 from gse. gmu. edu/research/Imtip/arp/voll Word/A.Lepley.

Lunz, -..... (1974). The effect of ovent dramatic enactment on communication effectiveness and role-taking ability. Unpublished Dissertation, Northwestern University. Retrieved April 20, 2006 from.
Maley, A. and D., A. (1982). Drama Techniques in Language Learning. Uk: Cambridge University Press.

McCaslin, N. (1999). Creative Drama In The Classroom And Beyond. New York: Addison Wesley.

Pellegrini, A. D. (1984). The effect of dramatic play on children's generation of cohesive text discourse processes, Discourse Processes, 7, 57-67.

Pellegrini, A. D. (1980). Symbolic functioning and children's early writing: Relations between kindergarteners' play and isolated word writing fluency. Washington D.C.: Office of Educational Research an Improvement. (ERIC Document Reproduction Service No. ED 201 407.)

Podlozny, Ann. (2000). Strengthening verbal skills through the use of classroom drama. Journal of Aesthetic Education, 34(3-4): 239-276.

Saldana, J. (1995). Drama of Color: Improvisation With Multiethinic Folklore. Portsmouth: Heinemann.

Schaffner, M., Little, G., \& Felton, H. (1984). Drama, language and learning. Reports of the Drama and Language Research Project, Speech and Drama Center, Education Department of Tasmania, National Association for Drama in Education, Education Department of Tasmania.

Stern, S. (1980). Drama in second language learning from a psycholinguistic perspective. Language Learning $30,1,77-100$.

Stewig, J. (1986). Elementary school principals and creative drama. Youth Theater Journal, 1, 2, 15-18.

Tatar, S. (2002). Dramatic activities in language arts classrooms: Resource summary. ERIC Clearinghouse on Reading English and Communication Bloomington IN., Family Learning Association Bloomington IN. (ED469926). Retrieved October 18, 2004 from http://www.ericdigests.org/2003-3/arts.html.

Tuluk, N. (2004). Yaratıcı drama. PiVOLKA. 3, 10-12.

Üstündağ, T. (1999). Yaratıct dramamm bir yöntem olarak ilkögretimde kullantması. Öğrenmenin oluşımu: Ögretme, model, strateji ve teknikleri. ilköğretinde etkili ögresme ve ögrenme ögretmen el kitabı. Modül 1. Süleyman Demirel Üniversitesi, Burdur Eğitim Fakültesi, 117-133.

Wright. P. (1996). Creative drama and personal development: An inquiry into drama in education and development of self. Retrieved October 27, 2004, from http://fehps.une.edu.au/Education/CRILT/theses/ Wright-med.html

Waldscmidt, E. D. (1996). Teacher templates: Analysis frameworks developed by bilingual teachers. learning about creative drama. Paper presented at the Annual Meeting of American Educational Research Association. (NY, A pril 1996).

Wessels, C., (1987). Drama (Resource Books for Teachers). OUP. 


\title{
$\ddot{O}_{z e t}$ \\ Yaratıcı Drama Yardımıyla Ingilizce Derslerini Yaşamla Buluşturmak
}

\author{
Filiz RIZAOĞLU*
}

Dokuz Eylül Üniversitesi

\section{Giriş}

Sanatın en eski çeşitlerinden biri olan drama her zaman hayatın bir parçası olmuştur. Shakespeare'in dediği gibi: "Dünya bir sahnedir ve bizler de bu sahnenin oyuncularıyı.", "Yaşam" adlı oyun sayesinde drama, tiyatroda, televizyonda, radyoda hatta sokakta bile karşımıza çıkar. Bu yerlerden bir diğeri ise belki de bazılarımıza hayatlarında ilk defa dramayla tanışma olanağını sunan okuldur.

"Eğitimde drama" kavramılla drama eğitiminden ziyade dramanın bir ögretim aracı olarak işlevine değinilmektedir. Eğitim amaçlı ilk drama uygulamalarına antik Yunan çağlarında rastlanmaktadır. Orta Çağ'da drama dini bir eğitim aracı olarak önem kazanmıştır. "Bir öğretim aracı olarak dramanın geçmişi antik çağlara uzansa da günümüzde eğitimde drama kullanımı teknikleri oldukça değişmiştir." (McCaslin,1999, s. 255). 1950 ve 60'larda Slade ve Way dramanın çocukların kendini ifade etmesi ve yaratıcılığına katkısı bakımından yaratıcı dramanın gelişimsel yönünün üzerinde durmuşlardır (Dougill, 1989, s. 3). 1970'lerde bu iki ismi Heathcote izlemiştir. Aynı dönemde Bolton dramanın dil gelişimindeki rolünün altını çizmiştir. Türkiye'de ise bir öğretim tekniği olarak dramtizasyon 1926'da ilköğretim müfredatına alınmıştır (Üstündağ, 1999). 1980'lerde San, Levent; daha sonra Adıgüzel ve diğerleri tarafindan yürütülen gerek kuramsal gerek uygulamalı çalışmalarla yaratıcı dramanın ilk adımları atılmıştır. 1998'de yaratıcı drama, üniversitelerin anaokulu ve sınıf öğretmenliği bölümlerinde zorunlu ders olarak yerini almıştır (Tuluk, 2004).

Günümüzde dramayı eğitim programlarmın her aşamasına dahil etmenin yolları araştırılmaktadır. Bu çabaların belirli bir bölümü dramanın İngilizce öğretiminde rolünü artırmaya yöneliktir. Yabanci dil ögretiminde yaratıcı dramanın kullanımı da bu eğilimin bir sonucudur. Öğrencilerin kendilerine özgü dramatik durumlar yaratarak kendilerini keşfetmelerini sağlayan, doğaçlamaya dayalı ve biçimsellikten uzak bu drama çeşidi tüm dünyada İngilizce öğretmenlerinin ilgisini çekmektedir. Bu çalışma oldukça etkili ve gerçek yaşama yakın bir öğretim yöntemi olan yaratıcı dramanın İngilizce ögretiminde kullanım yollarını tanıtmayı amaçlamaktadır. Ayrıca yaratıcı dramanın yabancı dil olarak İngilizce öğrenen ögrencilere sunduğu yararların üzerinde durulmuş ve yaratıcı dramayı İngilizce derslerine katma amaçlı bazı önerilerde bulunulmuştur.

\section{Bir Öğrenme Süreci Olarak Yaratıcı Drama}

\section{A. Temel Özellikler}

Okul içi drama etkinliklerinin tiyatro sanatından ayırdedilmesi için İngiltere'de bu alan 
"Eğitimde Drama" ve Amerika'da "Yaratıcı Drama" adını almıştır. Yaratıcı drama rol oynama, doğaçlama ve eğitsel dramayı da içine alan geniş bir terimdir. Alanın resmi tanımı şöyledir:

Yaratıcı drama bir lider aracı- lığıyla katılımclların, deneyimleri üzerinde hayal etmeleri, canlandırmalar yapmaları ve derin düşünme gerçekleştirmelerini amaçlayan doğaçlamaya dayalı, gösteri amacı gütmeyen bir drama çeşididir. Yaratıcı drama ge-leneksel olarak çocuklara yönelik bir drama olarak düşünülse de süreç her yaştan insana uygundur. [1]

Yaratıcı drama bir fikir, kavram, hikaye, şiir veya bir durumun ögrenciler tarafından hiçbir hazırlık yapılmadan, o anda içlerine doğduğu gibi canlandırıldığı aktif bir süreçtir. Bu anlamda yaratıcı drama ögrencilerin Íngilizce'yi bir iletişim aracı olarak kullanarak öğrendiklerine ilişkin geridönüt vermelerini sağlar. Süreci dilin iletişimsel bir işlevi ya da öğrencilerin ilgisini çekecek bir durumla başlatmak, öğrenme süreci ve gerçek yaşam arasındaki bağın sağlam tutulmasını sağlar. Öğrencileri kendilerini ifade etmeleri için yeni yollar aramaya iten de bu yaşamla olan bağlantıdır. Hikaye ve şiir gibi edebiyat ürünlerinin yaratıcı dramada kullanımı dil öğrenimini pekiştirir. Öğrenciler hem yaşam hem de öğrenmeyi hedefledikleri dille ilgili örnekler görme imkanı bulurlar. Bu noktada yaratıcı dramanın oyun ve diğer edebiyat ürünlerinin yorumlanması anlamına gelmediğini, bu alanın tiyatronun kapsamına girdiğini vurgulamak gerekir. Yaratıcı dramanın amacı drama öğrenmek değil drama yoluyla ögrenmektir.

\section{B. Yaratıcı Dramanın Aşamaları}

\section{1) Isınmalar}

Isınmaların temel amacı öğrencilerin ortaklaşa drama yaratmaları için güvenli bir ortam oluşturmaktır. Güven sağlama ve fiziksel çalışmaları içerir. Sözlü veya sözsüz olabilir. Sözsüz ısınma çalışmalarına örnek olarak bir öğrencinin karşısındaki ne yaparsa aynısını yaptığı "Ayna" çalışması verilebilir. Sözlï ısınma kısmında topla tanışma oyunlarına yer verilebilir. Isınmalar sayesinde öğrencinin dikkatinin tek bir faaliyete odaklanması sağlanır, bunun da pandomim ve doğaçlama çalışmaları için büyük yararı vardır.

\section{2) Pandomim}

Öğrencileri pandomime alıştırmak için önce heyecan, şaşırma, korku gibi bazı duyguları mimik ve jestleri yardımıyla canlandırmaları istenebilir. Kelime ögretiminde anlam pandomim yoluyla verilebilir. Bushman'in (2001, s.55) belirttiğine göre araştırmalarda pandomim yoluyla ögrenilen kelimelerin daha iyi hatırlandığ ortaya koyulmuştur.

\section{3) Rol Oynama}

Rol oynama İngilizce öğretiminde yaygın olarak kullanılan tekniklerdendir. Maske veya kukla kullanımı öğrencinin rolüyle bütünleşmesine yardımcı olabilir. Sınıfta işlenen bir oyun, hikaye veya kitaptan bir parça alınarak öğrencilerden karakterleri canlandırmaları istenebilir. Bir konuşmada katılımcıların konuşma stillerinin önemine dikkat çekmek için öğrencilerden sırayla bir genç, bir yetişkin ve bir yaşlı gibi konuşacakları durumlar yaratmaları istenebilir.

\section{4) Doğaçlama}

Pandomim ve rol oynama ile öğrenciler her ne kadar dramaya ısınsa da doğaçlama yapmak ilk başta onlara zor gelebilir. Doğaçlamalara basit durumlarla başlanması daha sonra sürecin genişletilmesi tavsiye edilir. Doğaçlamaya alışık olmayan bir sınıfta diyalogların ezberlenmesiyle öğrencilerin drama sürecine alışmaları sağlanabilir. "Yabancı film" etkinliğinde, doğaçlama yaparken diğer iki öğrenci onları seslendirir. Kelimelerin anlamı da doğaçlama yapılarak verilebilir.

\section{5) Değerlendirme}

Değerlendirme, sürecin başında, ortasında veya sonrasında yapilabilir. Bu aşamada rol ve karakterlere eleştiriler yöneltilir. Yaşanılan deneyimlerin üzerinde konuşmak onların daha iyi hatırlanmasını sağlar. Sınıf İngilizce'nin ne kadar akıcı ve doğru olarak konuşulduğunu tartışabilir. En çok yapılan telaffuz hataları söylenebilir. $\mathrm{Bu}$ aşamada da diğerlerinde olduğu gibi öğrencilerin İngilizce konuşması teşvik edilir. 


\section{Yarattce Dramantn Faydalart}

Yaratıcı drama bireysel düzeyde öğrencinin olumlu bir benlik anlayışı, problem çözme becerileri, yaratıcılık ve sanatsal becerilerini geliştirmesini sağlar. Toplumun bir parçası olan bireye toplum bilinci kazandırır ve onu iş birliği içinde çalışmaya yöneltir. Yaratıcı dramanın yabancı dil öğrenenlere katkısı da oldukça fazladır. Ginnis (2002) öğrencilerin dört ortak özelliğini şöyle sıralar:

i) Herkes kendisi ile ilgili kararları kendisi vermek ister.

ii) Birden fazla duyuya hitap eden, dramatik, olağan dışı ve duygusal ağırlığı olan deneyimler sıradan deneyimlere göre daha fazla ve daha uzun süreli hatırlanır.

iii) Herkes kendisini duygusal ve psikolojik olarak güvende hissetmek ister.

iv) Öğrenciler kendi öğrenmeleri üzerinde söz sahibi olurlarsa daha güdülenmiş ve öğrenmeye hazır durumda olurlar. ( s.17)

Yaratıcı drama bu koşulların hepsini tam anlamıyla karşılayarak ögrencilere sayısız katkılar sunar. Hem sözlü hem de yazılı çalışımalara uyarlanabildiği için yabancı dil öğrencilerinin dört dil becerisini geliştirmelerine olanak verir.

\section{Yarattc Dramantn Ders Programına Altmmast}

Ingilizce öğretmenleri yeni bir konunun sunumunda, öğrenilmiş bir konunun pekiştirilmesinde ya da derste sadece öğrenme ortamına canlılık ve çeşitlilik katmak amacıyla yaratıcı dramadan faydalanabilir. Sürece başlamadan önce sıraların U şeklinde düzenlenmesi öğrencilerin rahat hareket etmeleri açısından önemlidir. Ayrıca zil, alkış gibi yaratıcı sürecin başlamasına işaret eden araçların kullanılması da tavsiye edilir. Öğretmen işlenecek konunun içeriğine göre drama faaliyetlerini belirler veya öğrenciler karar verme sürecine dahil edilir. Dramatik süreçte öğrenciye düşen görev Heathcote'un (1995) deyimiyle "uzman kimliğine" bürünerek hayali bir konumda uzman olarak hareket etmektir. Pandomim gibi çalışmalara yer verildiği için her öğrencinin, konuşmasa veya oynamasa bile yaratıcı dramaya dahil olma imkanı vardır. Öğretmene düşen görevse bir nevi rehberlik veya kolaylaştırıcılıktır. Öğretmen de dramaya dahil olabilir, fakat oyun içinde yetkiye sahip bir rol almamalıdır.

\section{Sonuc}

Temelde doğaçlamaya dayalı bir drama çeşidi olan yaratıcı drama yabancı dil olarak Ingilizce eğitiminde önemli bir öğretim aracıdır. İngilizce öğretiminde en son yaklaşımların öğrenci-merkezli, iletişime dayalı, gerçek yaşama sıkı sıkıya bağlı yöntemleri benimsediği günümüzde, yaratıcı drama tüm bu koşulları sağlayan tek, yöntem olarak karşımıza çıkmaktadır.

Dramatik süreç basit ısınmalarla başlayan ve yaratıcı ve özerk doğaçlamalara doğru ilerleyen aşamalı bir süreçtir. Bu süreçte yaşları ne olursa olsun öğrenciler çeşitli gelişimsel, eğitimsel ve dilsel kazanımlar sağlarlar. Dahası öğrenme ortamı yaratıcı dramanın eğlenceli ve dinamik yapısı sayesinde canlanır, yaşamla buluşur. Bütün bunlar göz önüne alındığında İngilizce öğretmenlerine düşen görev açıktır. Yaratıcı dramanın Ingilizce derslerinde etkili bir şekilde kullanımı etkili ve gerçek bir öğretme/öğrenme sağlayacaktir.

[1] Jed H. Davis and Tom Behm. (1978) Terminology of Drama/Theatre with and for Children: A Redefinition, Children's Theater Review. Vol. 27. pp. 10-11. 